\title{
Homeopathy in Oncological Care
}

\section{Kalyan Gaddam* and Todd A Born}

Integrative Oncology, Comprehensive Blood and Cancer Center, USA

*Corresponding Author: Kalyan Gaddam, Integrative Oncology, Comprehensive Blood and Cancer Center, USA.

Received: August 22, 2019; Published: September 24, 2019

DOI: 10.31080/ASMS.2019.03.0415

\begin{abstract}
Cancer is the second leading cause of death in the United States. Conventional cancer treatment options include chemotherapy, radiation and surgery. Cancer treatments are stressful, and often results in the patient (and family), suffering both physically and mentally, which typically negatively affects quality of life (QOL). Chemotherapy and radiation, albeit may be lifesaving or prolong, are known to cause many side-effects, including but not limited to oral mucositis, neuropathies, nausea, vomiting, skin eruptions, anxiety, depression, pain, and organ damage. Most of treatments available for these side-effects are short-term, and often times are ineffective. Homeopathic medicines are widely used to treat side-effects of chemotherapy and radiation, without any known negative interactions. Here we present 21 cancer patients who were treated for their side-effects with homeopathy.
\end{abstract}

Keywords: Homeopathy; Cancer; Oncology; Mucositis; Cancer Side-Effects; Radiation Side-Effects; Chemotherapy; Radiation

\section{Introduction}

Cancer is the second leading cause of death in the United States [1]. Cancer and its treatment have a significant impact on physical and emotional well-being. Cancer treatments often negatively impact quality of life due to side-effects. In a prospective, observational study done in Switzerland and Germany, the effectiveness and value of homeopathic medicine with conventional care was evaluated. The study found that patients treated with homeopathy and conventional care had improved quality of life compared to the group which received only conventional care [2]. Similarly, a randomized controlled trial of 285 patients who received homeopathic care along with standard conventional care, showed that the homeopathic treatment arm had a significantly better global health status and improved quality of life [3]. Below, we present 21 case reports that were treated with homeopathy during conventional cancer care. We here attempting to show the quick result and efficacy of homeopathic medicines in severe pathological conditions.

\section{Patient 1}

DB, a 63 year old female with ovarian cancer presented initially in September 2014 with concerns of headache and sinusitis. She had been actively under chemotherapy at that time. She notes that since the start of chemotherapy her headaches have been worse. She reports pain at the root her nose with viscid post nasal discharge. On examination, she had tenderness over palpation of her sinuses. She was started on Kali bichromicum $20^{\circ} \mathrm{c}^{*}$. She was advised to use Kali bichromicum $20^{\circ} \mathrm{c}$ every four hours for two days. Within a day she felt completely better. She had no headaches and sinuses have not bothered her. She repeated Kali bichromicum 200c as needed for sinusitis. There was no change in any of her medication during this treatment.

Eight months later, she presented with concerns of dizziness and dazed feeling after attending a cancer fundraiser. The day after the cancer fundraiser she was exhausted, weak and dizzy. She started on Gluonium $20^{\circ} \mathrm{c}$ while she was getting her MRI done. She was advised to take Gluonium $20^{\circ} \mathrm{c}$ every two hours till the symptoms resolve. She felt much better by end of the day and completely better by next day. She repeated the remedy for two days. She had no fatigue and her dizziness completely resolved. She unfortunately did show some questionable lesions on MRI. She was started on radiation to her brain. She maintained very good quality of life during 
her radiation treatments. She used Gluonium $20^{\circ} \mathrm{c}$ as needed when she had dizzy spells. She is alive and doing very well.

\section{Patient 2}

RW, a 57 year old female with squamous cell carcinoma of the mandible, was referred by the radiation department for her concerns with oral mucositis. At the time of presentation she was unable to open her mouth, nor able to chew any food. She was not able to talk fluently either. Physical examination was quite difficult as she was not able to open her mouth without significant pain. She was initially started with Mercurius solubilize $20^{\circ} \mathrm{c}$ every three hours. She improved, but improvement was not significant. She was then started on Borax $20^{\circ} \mathrm{c}$ every three hours. She improved rapidly and within a week she was almost completely better. She was able to talk fluently and was able to open her mouth and eat food. Once the improvement began she was advised to use Borax $20^{\circ} \mathrm{C}$ as needed only. She had to use Borax $20^{\circ} \mathrm{c}$ for one week and after a week she used it only when her symptoms start appearing. She finished her radiation treatments and responded very well.

\section{Patient 3}

MS, a 50 year old Hispanic female presented in June 2015, with concerns of severe pain from her recent breast cancer diagnosis. She also was very anxious and feared of dying. She was waiting for surgical resection at that time. She initially started on Asteria rubens 30c. once at night for one week. Her pain improved significantly, but she still struggled with anxiety and fear of death. She was started on Agaricus muscaris $20^{\circ} \mathrm{c}$ only one dose at night for one day. She improved rapidly and her anxiety was much better. She was not under any treatment at this time and she was still waiting for her surgical resection.

\section{Patient 4}

LH, a 50 year old female presented with anxiety and fear of dying. She presented with these concerns with her 1999 breast cancer diagnosis. She had colon polyps removed in 2011, with tabular adenoma, with inflammation. She was very anxious. A small change in lab results or any news in her family would cause significant panic attacks. She was unable to live her life because of her panic attacks. Her examination was unremarkable. She was started on Arsenicum album 1M one dose at night for one day. She felt much better within one week. She was not under any treatment during his time.

\section{Patient 5:}

JD, a 56 year old male who presented with concern of severe rectal pain, secondary to radiation for his rectal cancer that was diagnosed in January 2015, and started radiation with 5-fluorouracil (5-FU). He described his pain as 10/10, 10 being the worst. He also had severe hemorrhoids causing more discomfort. He was already on hydrocodone-acetaminophen with no significant benefit. External examination revealed significantly inflamed areas. He was started on Aloe $20^{\circ} \mathrm{c}$ every three hours, but there was no significant change in his condition. He was then started on Aesculus 200c every three hours. There was 30\% improvement in his pain, but still had very severe pain interfering with his daily living. He was started on Nitric acid 3c every three hours. His improvement was rapid and had much better pain control. His pain was $80 \%$ better within couple of days and well controlled. There was no change in his treatment during the intervention. Even with hydrocodone, nitric acid 3c was the only one which helped him with his pain control. He finished radiation with a better quality of life. He continued with nitric acid $3 c$ during his radiation treatment period.

\section{Patient 6}

DM, 61 year old male presented in November 2015, with concerns of oral mucositis. He had been receiving Cisplatin/5 - FU with his radiation for squamous cell carcinoma of the left tonsils. He reports significant pain on swallowing and mouth sores. He was unable to eat food or liquids. He was started on Magic mouthwash and Diflucan with no benefit. On examination, tongue appeared thick, dirty white on and with buccal ulcers and ulcerated gums. He was started on Borax $20^{\circ} \mathrm{c}$ every three hours and when improvement decrease to four times a day during his treatment period. He improved slowly, but his sores and pain were much better by end of the second week. He notes that the Magic mouthwash keeps the pain away for 30 seconds compared to Borax 200c, which keeps the pain away for 30 minutes and this has enabled him to eat much more easily. He continued his radiation treatment and his pain and sores are much better controlled.

\section{Patient 7}

JL, a 60 year old female diagnosed with breast and thyroid cancer presented as add-on assessment in May, 2014 for concerns with dizziness and vertigo. She reports a history of hearing impairment and had similar episodes in the past. Examination was unremarkable. She was started on Conium $20^{\circ} \mathrm{c}$ three doses four hours apart. 
Within couple of days her vertigo had completely resolved. She was on thyroid suppression therapy at the time of treatment.

\section{Patient 8}

TG, a 54 year old female presented with concerns of pain in her left upper extremity, secondary to lymphedema. She reports of pain radiating from her medial axillary region to her elbow. Pain 8 $9 / 10,10$ being the worst. She was unable to move the arm because of the pain. She could not afford a sleeve. She was not willing to do complete decongestive therapy because of family issues. On examination, limited range of motion of left extremity was noted because of the pain. No significant change in her arm measurements compared to unaffected arm. She was started on Agaricus $20^{\circ} \mathrm{c}$. every four hours for two days. At her two week follow-up, she reports significant improvement in terms of pain control. After four weeks, her pain had completely resolved. There was no change in treatments during the treatment.

\section{Patient 9}

ES, a 50 year old, presented with persistent nausea during radiation for her squamous cell carcinoma of her nose. She was on anti-nausea medication with no benefit. She was started on Ipecac 200 c. Her nausea improved promptly. None of her medications changed during the treatment.

\section{Patient 10}

MG, a 57 year old female presented for concerns with persistent nausea during her Folfiri (Folinic acid, Fluorouracil. Irinotecan) based chemotherapy regimen. She was on anti-nausea medications but with no benefit. She was started on Ipecac $20^{\circ} \mathrm{c}$ and she promptly improved. Her disease progressed and was unfortunately moved to hospice care. Her family was very grateful for the improvement of her nausea.

\section{Patient 11}

ME, a 45 year old female seen as add-on assessment for concerns with headache and heaviness of the eyes for the past two days. Pain in the head was 10/10,10 worst, and was unable to see the light with significant heaviness of the eyes. She was extremely tired. Examination was unremarkable. She was on tamoxifen. She was started on Gelsemium $20^{\circ} \mathrm{c}$ four hours apart for one day. She improved rapidly and completely recovered within two days. There was no change in her treatment during this care.

\section{Patient 12}

TM, a 53 year old female presented with concerns with incontinence and anxiety. She had been diagnosed with rectal cancer and currently on observation. She has accidents every time she exerts herself. Incontinence started with her pregnancy. She was started on Sepia $20^{\circ} \mathrm{C}$ one dose at night for one day only. Couple weeks later she reported $90 \%$ improvement in her incontinence. She continued with Sepia $20^{\circ} \mathrm{C}$ one dose at night as needed. She later relocated for oncological care.

\section{Patient 13}

CN, a 76 year old initially presented in October 2015, for concerns about her migraine, depression and insomnia. Her migraines occur twice a week and had been increasing since the diagnosis. She also has been fighting with moderate depression and insomnia since the diagnosis. She was diagnosed with breast cancer in October 2014. Examination was unremarkable. She was on Femara $2.5 \mathrm{mg}$. She was started on Natrum muriaticum $20^{\circ} \mathrm{c}$ one dose at night for seven nights followed with Natrum muriaticum $12 \mathrm{X}$ every four hours. On four week follow-up patient reports less frequent migraines, was less depressed and had been sleeping well.

\section{Patient 14}

HM, a 67 year old female presented with fibromyalgia and pain in her eyes. She had significant injection, itching and lachrymation. She described her sensations as having sand in her eyes. She described pain with eye movements. She attributes the eye discomfort to allergies. Examination showed significant injection of her sclerae. Ophthalmological examination showed nothing remarkable. She was on observation for her breast cancer. She was started on Pulsatilla $20^{\circ} \mathrm{c}$ three hours apart for three doses. She improved rapidly and eye pain resolved completely in couple of days. She used Pulsatilla $20^{\circ} \mathrm{c}$ as needed.

\section{Patient 15}

GH, a 62 year old male with prostate cancer presented with concerns of stomach pain, gas and bloating. Pain was located to his epigastric region with cramping. He notes that pain is especially worse since radiation treatment, but also did have a history of gastrointestinal issues. Examination showed a bloated abdomen with diffuse tenderness on palpation to the entire abdomen. He was started on Carbo veg $20^{\circ} \mathrm{c}$ three doses three hours apart. He reported that his stomach pain and cramping was gone by the end of the week and 
had been doing well. There was no change in his medications during this time.

\section{Patient 16}

LK, an 89 year old female with history of melanoma presented with concerns of sciatica. She was on fentanyl pain patches. She recently had an exacerbation of sciatic pain. She complains of pain shooting down her leg. Pain 10/10. She reports that she was given Hydrocodone, which unfortunately caused constipation. She however, took hydrocodone off and on. She was started on Rhus toxicodendron $20^{\circ} \mathrm{c}$ every four hours for two days and within the end of the week her pain improved. She was able to function better. She took Rhus toxicodendron $20^{\circ} \mathrm{C}$ whenever she had noticed the pain in place of hydrocodone and had similar improvement in pain with no constipation.

\section{Patient 17}

KW, a 69 year old female with metastatic urothelial cancer presented with concerns of rectal incontinence. She had been having problems with incontinence, which had been negatively affecting her quality of life. Incontinence was not related to her cancer. She recently finished radiation. Examination was unremarkable. She was started on Aloe 30c three doses eight hour apart for one day. On follow-up, she reports significant improvement in her incontinence. Aloe 30c three doses eight hours apart for one day was repeated again after three months for her incontinence with similar results. There was no change in treatment during the treatment period.

\section{Patient 18}

AS, a 55 year old female, with history of breast cancer presented with concerns of pain in her arm secondary to lymphedema. She was unable to lift her arm and pain was 10/10, 10 worst. Pain was located on the medial surface of the arm, extending from the axilla to her elbow. Examination showed decreased range of motion and an arm circumference that was increased compared to the unaffected side. She was on radiation treatment. Because of family issues she was unable to complete decongestive therapy. She was started on Agaricus $20^{\circ} \mathrm{c}$ every four hours for two days. She noted prompt improvement in her pain. By end of the third week she had no pain and had done very well.

\section{Patient 19}

MR, a 51 year old female with spindle cell cancer of her thigh presented with severe pain at site of radiation. She had surgical resection and radiation to the midline of her thigh. She notes pain of 10/10, 10 worst. On examination, significant tenderness on palpation and heat radiated from the region. She was started on Arnica $3 c$ every six hours till improvement is noticed and within three weeks she improved dramatically with very minimal pain.

She later presented with concerns of nausea during her radiation treatment. She was started on Ipecac $20^{\circ} \mathrm{C}$, one dose during the office visit and if needed to be repeated after six hours. Ipecac $200 \mathrm{ch}$ promptly relieved her nausea. She later presented with headaches and weakness. She notes pain of throbbing and pain radiating from occiput to forehead especially right eye. She was started on Sanguinaria $20^{\circ} \mathrm{c}$ three doses three hours apart which promptly relieved her headaches. She had used Sanguinaria $20^{\circ} \mathrm{c}$ in similar dosing off and on during her headaches with excellent results.

\section{Patient 20}

$\mathrm{BD}$, a 60 year old female nurse with history of Non-Hodgkin's lymphoma (NHL) in 1988 and squamous cell carcinoma (SCC) of the tongue in 2000, presented to the clinic. She had excision of the SCC on the right side of the tongue. In October 2010, the patient had vaccinations to go out of the country. She cannot remember what they were. After a day she thought she had an allergic reaction, so she took Benadryl and went on the trip. On her trip she noticed that her mouth was very sore. When she came back she was given Diflucan, but since then never recovered. It started with soreness of her tongue and diffusely disseminated blisters. Unable to open her mouth, nor talk, chew food and pain 10/10, 10 worst. She cannot tolerate anything hot, nor cold. Eventually she was diagnosed with Lichenoid Mucositis via biopsy and showed significant inflammation. She had suffered with this for the past four years with no benefit. Initially she started with Mercurius corrosive $20^{\circ} \mathrm{c}$ every three hours for two days with no benefit. She also tried Borax $20^{\circ} \mathrm{c}$ three hours apart for three days as well with no benefit. The inflammation and burning persisted with pain 10/10. She was then started with Cantharis $20^{\circ} \mathrm{c}$ every three hours for three days. On follow-up, the patient was able to talk better, less pain and had resolution of all mouth sores and the oral candidiasis had almost completely resolved. She had been on the same medication list for the past two to three years, on and off. None of the medications were changed during this period. She also was on L-glutamine 10 grams three times a day for four weeks, but no considerable change in her symptoms until she started Cantharis 200c. 


\section{Patient 21}

$\mathrm{AB}$, a 45 year old female with squamous cell carcinoma presented in December 2015, with concerns of oral mucositis from radiation treatments. She reports pain 10/10, 10 worst, unable to open her mouth, speak and experienced odynophagia. Examination showed thick white coating of the tongue. She had been on Diflucan and Magic mouthwash with no significant change in her symptoms. She was started on Borax $20^{\circ} \mathrm{c}$ every three hours till improvement is noticed and decrease to three times a day after that. On follow-up, she reports significant improvement of mouth sores and pain. Her pain was 3/10 on day three and continued to improve throughout her radiation treatments. She was able to eat, speak more fluently and able to swallow. She still struggles with pain, but she notes the pain is $70 \%$ better. She continues to followup and had been doing very well. Sometimes, in cases where one is still undergoing radiation, they may not be $100 \%$ pain free.

\begin{tabular}{|c|c|c|c|c|c|}
\hline $\begin{array}{l}\text { Patient } \\
\text { initials }\end{array}$ & $\begin{array}{l}\text { Age/ } \\
\text { Sex }\end{array}$ & Cancer & Chief Complaint(s) & $\begin{array}{l}\text { Current/past } \\
\text { conventional tx }\end{array}$ & $\begin{array}{l}\text { Homeopathic treatment and } \\
\text { Response }\end{array}$ \\
\hline DB & $63 / F$ & $\begin{array}{l}\text { Ovarian Cancer - } \\
\text { Stage IV } \\
\text { T3b,N1,M1 }\end{array}$ & $\begin{array}{l}\text { In Sep 2014, patient presented } \\
\text { with chronic sinusitis and } \\
\text { headaches, pain at the root } \\
\text { of her nose, viscid discharge } \\
\text { since she started with chemo- } \\
\text { therapy. She has a history of } \\
\text { sinusitis, but since chemo she } \\
\text { reports that her sinus problem } \\
\text { has been much worse. After } \\
\text { nine months, she followed up } \\
\text { feeling dizziness and dazed. } \\
\text { She was at a cancer fundraiser } \\
\text { in mid-afternoon, on a hot day. } \\
\text { Since then she started having } \\
\text { this dizziness and dazed feel- } \\
\text { ing. She was immediately sent } \\
\text { for a brain MRI. }\end{array}$ & $\begin{array}{l}\text { She completed a } \\
\text { Carboplatin based } \\
\text { regimen. No change } \\
\text { in her medications. }\end{array}$ & $\begin{array}{l}\text { Started on Kali Bichromicum } 200 \text { c } \\
\text { every } 4 \text { hours, which cleared up her } \\
\text { sinus issues promptly within couple } \\
\text { of days. } \\
\text { For her Dizziness and dazed feeling } \\
\text { she was started on Gloninum 200c, } \\
\text { while she was getting her MRI done } \\
\text { for her brain. The MRI showed ques- } \\
\text { tionable lesions. But none where } \\
\text { conclusive. She felt better within the } \\
\text { day she started Gloninum. She was } \\
\text { completely better by the next day, } \\
\text { as if she had not had any problem. } \\
\text { Her recovery was remarkable after } \\
\text { Gloninum. She did undergo cyber } \\
\text { knife treatment, but still maintained } \\
\text { very good health. }\end{array}$ \\
\hline RW & $57 / F$ & $\begin{array}{l}\text { Squamous cell } \\
\text { carcinoma of } \\
\text { mandible - Stage } \\
\text { 1A T1b,N0,M0 }\end{array}$ & $\begin{array}{l}\text { Patient initially presented with } \\
\text { oral mucositis from radiation } \\
\text { to the mandible. She was un- } \\
\text { able to open her mouth, nor } \\
\text { able to chew food. She had } \\
\text { significant pain. She was un- } \\
\text { able to talk fluently. }\end{array}$ & $\begin{array}{l}\text { She started on ra- } \\
\text { diation treatments. } \\
\text { She received seven } \\
\text { weeks of radiation } \\
\text { treatments, five } \\
\text { times a week. She } \\
\text { was already on } \\
\text { magic mouthwash } \\
\text { with no benefit. }\end{array}$ & $\begin{array}{l}\text { Started on Mercurius corrosive } \\
\text { 200c, with no significant benefit. She } \\
\text { then started on Borax 200c and she } \\
\text { improved rapidly. }\end{array}$ \\
\hline MS & $50 / F$ & $\begin{array}{l}\text { Breast cancer - } \\
\text { Stage IIA } \\
\text { T2,N0,M0 }\end{array}$ & $\begin{array}{l}\text { In June } 2015 \text {, the patient } \\
\text { presented with a recent diag- } \\
\text { nosis of breast cancer. At this } \\
\text { time she was waiting for the } \\
\text { surgical resection and further } \\
\text { treatment plans from her on- } \\
\text { cologist. She had been having } \\
\text { severe pain from her affected } \\
\text { breasts. She also was very } \\
\text { anxious. She felt the anxiety in } \\
\text { the pit of her stomach. She was } \\
\text { afraid she was going to die. }\end{array}$ & $\begin{array}{l}\text { She had not started } \\
\text { on any treatments } \\
\text { during this time. } \\
\text { No change in her } \\
\text { medications. }\end{array}$ & $\begin{array}{l}\text { She was given Asteria rubens } 30 \mathrm{c} \\
\text { every } 6 \text { hrs and followed up in one } \\
\text { week. She reported that her pain } \\
\text { was better but, still significantly } \\
\text { anxious. } \\
\text { She was then given Agaricus } 200 \mathrm{c} \\
\text { every } 6 \text { hrs. Both her pain and anxi- } \\
\text { ety significantly improved. }\end{array}$ \\
\hline
\end{tabular}




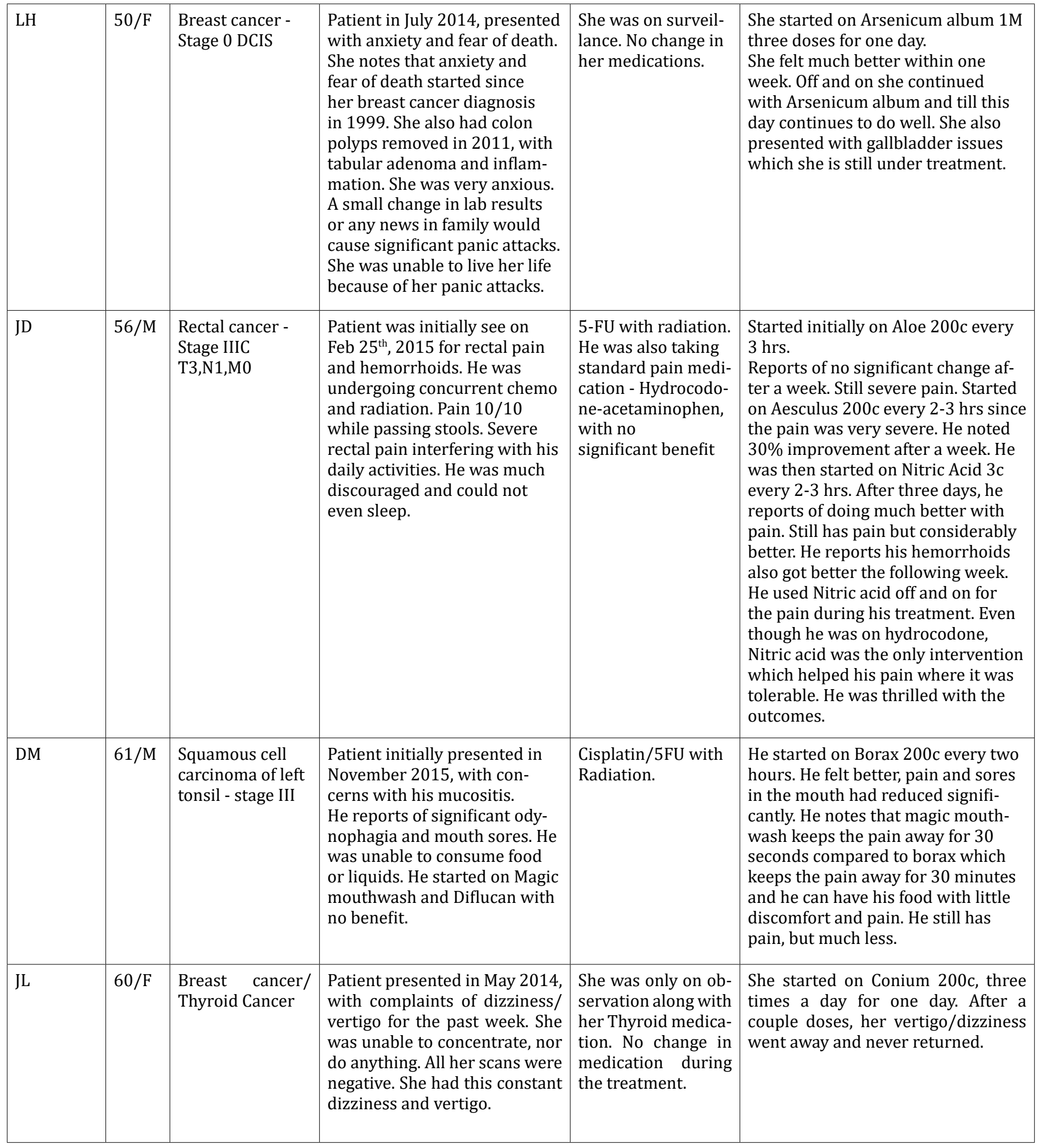




\begin{tabular}{|c|c|c|c|c|c|}
\hline $\mathrm{TG}$ & $54 / F$ & $\begin{array}{l}\text { Breast Cancer - } \\
\text { Stage IIA } \\
\text { T2,N0,M0 }\end{array}$ & $\begin{array}{l}\text { Patient presents with pain } \\
\text { in her left upper extremity } \\
\text { secondary to lymphedema. } \\
\text { Patient could not afford the } \\
\text { sleeve. She was not willing to } \\
\text { do the complete decongestive } \\
\text { therapy as she needs to take } \\
\text { care of her family. }\end{array}$ & $\begin{array}{l}\text { She was on obser- } \\
\text { vation at this time }\end{array}$ & $\begin{array}{l}\text { She started on Agaricus 200c every } \\
\text { four hours. She started improving } \\
\text { and was not in pain after two weeks. } \\
\text { She uses Agaricus off and on when } \\
\text { she does strenuous activities. }\end{array}$ \\
\hline MG & $57 / F$ & $\begin{array}{l}\text { Colon Cancer - } \\
\text { Stage IIIB }\end{array}$ & $\begin{array}{l}\text { Patient was seen on December } \\
07,2015 \text {, for concerns with } \\
\text { persistent nausea. She had } \\
\text { been on various anti-nausea } \\
\text { meds with little benefit. }\end{array}$ & $\begin{array}{l}\text { Started on FOLFIRI } \\
\text { based chemothera- } \\
\text { py regimen }\end{array}$ & $\begin{array}{l}\text { Patient's family reported significant } \\
\text { improvement in her nausea after } \\
\text { Ipecac } 200 . c \text { Since her disease was } \\
\text { progressing she was moved to Hos- } \\
\text { pice care. }\end{array}$ \\
\hline ME & $45 / F$ & $\begin{array}{l}\text { Breast cancer - } \\
\text { Stage 1A }\end{array}$ & $\begin{array}{l}\text { Patient presented on March } \\
04,2015 \text { with headache and } \\
\text { heaviness of eyes for the past } \\
\text { few days. Head pain } 10 / 10 \text { and } \\
\text { cannot bare to see the light } \\
\text { and deal with her heaviness of } \\
\text { the eyes. }\end{array}$ & $\begin{array}{l}\text { She was on } \\
\text { Tamoxifen. No other } \\
\text { change in her medi- } \\
\text { cations. }\end{array}$ & $\begin{array}{l}\text { Started on Gelsemium 200c every } \\
\text { three hours and within the next } 12 \\
\text { hours felt much better and no more } \\
\text { headaches and heaviness of the eyes. }\end{array}$ \\
\hline TM & $53 / F$ & $\begin{array}{l}\text { Rectal cancer - } \\
\text { Stage IIIB }\end{array}$ & $\begin{array}{l}53 \text { year old female presented } \\
\text { on Aug } 13 \text { th, } 2015 \text {, for con- } \\
\text { cerns about her nutrition, } \\
\text { incontinence and anxiety. } \\
\text { Patient notes that she always } \\
\text { has this incontinence with } \\
\text { bearing down. She had this } \\
\text { problem of incontinence since } \\
\text { her pregnancy. }\end{array}$ & $\begin{array}{l}\text { On observation. No } \\
\text { change in medica- } \\
\text { tions during the } \\
\text { treatment. }\end{array}$ & $\begin{array}{l}\text { She was started on Sepia } 200 \text { c, three } \\
\text { times a day for one day. } \\
\text { She reports that after Sepia } 200 \text { c her } \\
\text { incontinence was } 90 \% \text { better. Her } \\
\text { anxiety was also better. She followed } \\
\text { up for another couple of weeks and } \\
\text { then moved to Fresno for her treat- } \\
\text { ments. }\end{array}$ \\
\hline $\mathrm{HM}$ & $67 / F$ & $\begin{array}{l}\text { Breast Cancer - } \\
\text { Stage 1A }\end{array}$ & $\begin{array}{l}\text { Patient initially presented with } \\
\text { fibromyalgia and breast cancer. } \\
\text { On May 14th, 2013, she also } \\
\text { presented with concerns with } \\
\text { eye pain. Itching and redness } \\
10 / 10 \text {. She had been to vari- } \\
\text { ous ophthalmologists. She had } \\
\text { been struggling with this for } \\
\text { many years. Her eyes were in- } \\
\text { jected with lacrimation. }\end{array}$ & $\begin{array}{l}\text { She was on observa- } \\
\text { tion at this time. }\end{array}$ & $\begin{array}{l}\text { She started on Pulsatilla } 200 \text { c, every } \\
\text { four hours for two days. Her pain } \\
\text { and redness resolved within couple } \\
\text { of doses. }\end{array}$ \\
\hline
\end{tabular}




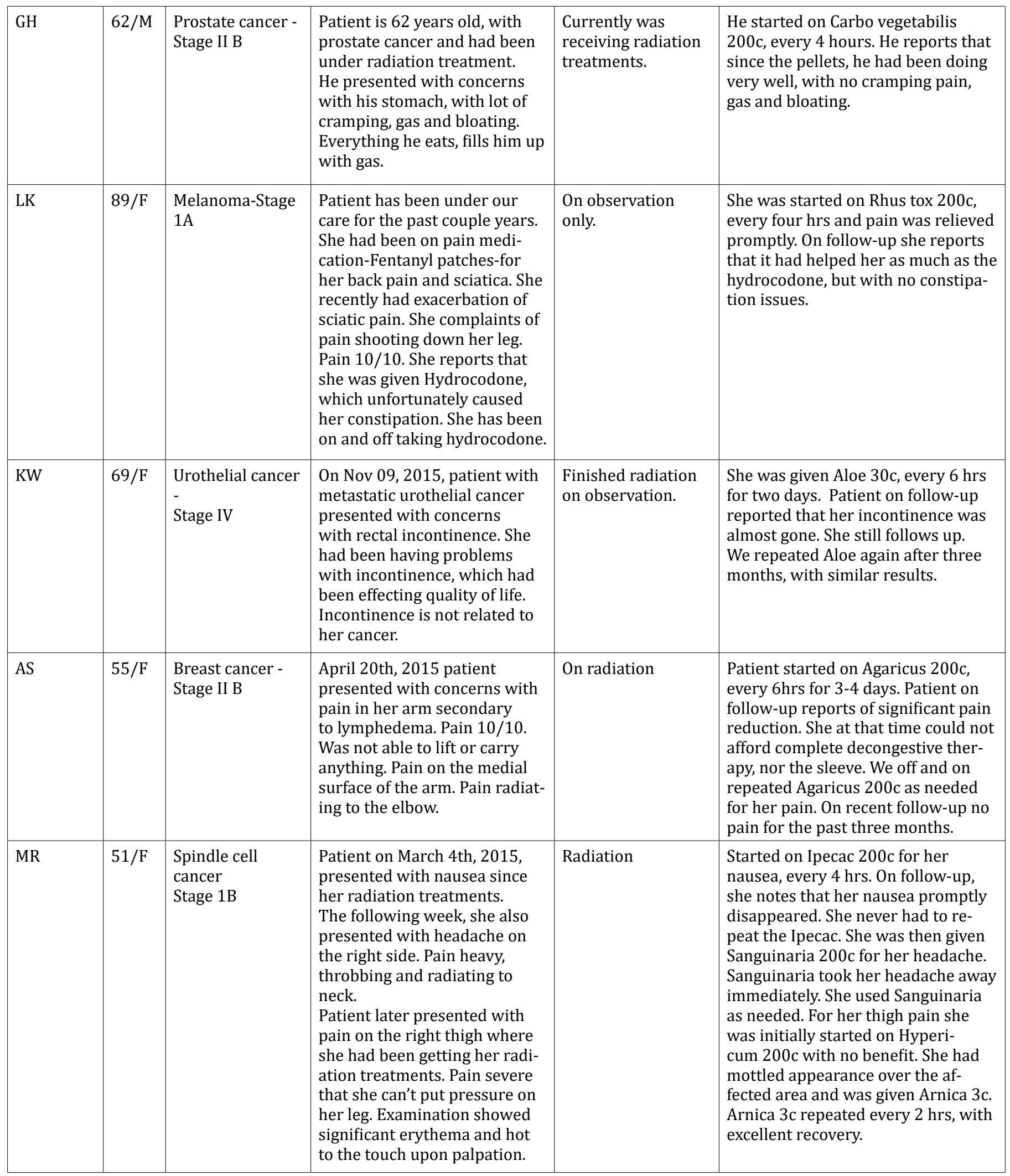




\begin{tabular}{|c|c|c|c|c|c|}
\hline BD & $60 / F$ & $\begin{array}{l}\text { History of Non- } \\
\text { Hodgkin's } \\
\text { lymphoma, } \\
\text { Squamous cell } \\
\text { carcinoma of the } \\
\text { tongue. She had } \\
\text { excision of SCC } \\
\text { on the right side } \\
\text { of the tongue }\end{array}$ & $\begin{array}{l}\text { In October 2010, the patient } \\
\text { had vaccinations for foreign } \\
\text { travel. She cannot remember } \\
\text { what they were. After a day, } \\
\text { she thought she had an allergic } \\
\text { reaction. Took Benadryl and } \\
\text { went on the trip. On her trip } \\
\text { she noticed that her mouth } \\
\text { was very sore. When she came } \\
\text { back she was given Diflucan. } \\
\text { But since then never recov- } \\
\text { ered. She started with sore- } \\
\text { ness of tongue and blisters } \\
\text { all over. Unable to talk, chew } \\
\text { food and pain } 10 / 10 . \text { Cannot } \\
\text { tolerate anything hot and cold. } \\
\text { Eventually was diagnosed } \\
\text { with Lichenoid Mucositis from } \\
\text { biopsy and showed significant } \\
\text { inflammation on biopsy. She } \\
\text { had these complaints for the } \\
\text { past four years. She had his- } \\
\text { tory of Non-Hodgkin's lympho- } \\
\text { ma in 1982-83. Then again in } \\
1988 \text {, for which she received } \\
\text { radiation to her neck and } \\
\text { chemotherapy. Later in } 2000 \text {, } \\
\text { she developed Squamous cell } \\
\text { carcinoma on the right side of } \\
\text { her tongue. She had excision } \\
\text { with clear margins. }\end{array}$ & $\begin{array}{l}\text { Past chemo in- } \\
\text { cluded - Mustard } \\
\text { nitrogen, procarba- } \\
\text { zine, } \\
\text { prednisone (MOPP), } \\
\text { ABVD (Adriamycin, } \\
\text { Bleomycin, Velban, } \\
\text { and DTIC), CHOP } \\
\text { (Cytoxan, adriamy- } \\
\text { cin, oncovorin and } \\
\text { procarbazine), and } \\
\text { radiation to right } \\
\text { side of the tongue. } \\
\text { Also tried Colchi- } \\
\text { cine. } \\
\text { Current Medica- } \\
\text { tions: Prozac, } \\
\text { losartan, Prilosec, } \\
\text { thyroid, Valtrex, } \\
\text { fluconazole, pilo- } \\
\text { carpine, nystatin, } \\
\text { Aller-Tec, Ambien, } \\
\text { Xanax as needed } \\
\text { and Vicodin. }\end{array}$ & $\begin{array}{l}\text { Initially she, started with Merc Cor } \\
200 \text { c, every } 2 \text { hrs but no change. } \\
\text { Then Borax } 200 \text { c, still no change. } \\
\text { The inflammation and burning } \\
\text { persisted. Pain } 10 / 10 \text {. Then moved } \\
\text { to Cantharis } 200 \text { c, every } 2 \text { hrs. } \\
\text { Followed up in one week. Patient } \\
\text { was able to speak better and had } \\
\text { complete resolution of all mouth } \\
\text { sores, and thrush almost completely } \\
\text { eradicated. She had been on and } \\
\text { off the same medication list for the } \\
\text { past two to three years. None of the } \\
\text { medication were changed during } \\
\text { this period. She also was taking } \\
\text { Glutamine } 10 \text { g, three times a day for } \\
\text { four weeks till then, but no consid- } \\
\text { erable change until we started on } \\
\text { Cantharis } 200 \mathrm{c} \text {. }\end{array}$ \\
\hline
\end{tabular}

Table: Summary of patient reports.

\section{Conclusion and Future Strategies}

In conclusion, we have shown the efficacy of homeopathic medicines in adjuvant to conventional oncological care, in 21 separate cases. Homeopathic medicines are non-toxic, have no known negative interactions with conventional cancer care, and are inexpensive medicines with strong patient adherence. Several other trials have been published on the effectiveness of homeopathic adjuvant in cancer care $[4,5]$. All the patients in the study had no change in their medications during their care, with one exception: that patient is currently is hospice as of the writing of this publication. All patients have continued to follow up and have maintained a good quality of life. 


\section{Bibliography}

1. Leading Causes of Death (2015).

2. Rostock M., et al. "Classical homeopathy in the treatment of cancer patients-a prospective observational study of two independent cohorts". BMC Cancer 11 (2011): 19.

3. Frass M., et al. "Influence of adjunctive classical homeopathy on global health status and subjective well-being in cancer patients-a pragmatic randomized controlled trial". Complementary Therapies in Medicine 23.3 (2015): 309-317.

4. M Oberbaum., et al. "A randomized, controlled clinical trial of the homeopathic medication TRAUMEEL $S$ in the treatment of chemotherapy-induced stomatitis in children undergoing stem cell transplantation". Cancer 92.3 (2001): 684-690.

5. Pommier P., et al. "Phase III randomized trial of Calendula officinalis compared with trolamine for the prevention of acute dermatitis during irradiation for breast cancer". Journal of Clinical Oncology 22.8 (2004): 1447-1453.

Volume 3 Issue 10 October 2019

(c) All rights are reserved by Kalyan Gaddam and Todd A Born. 